\title{
Folklore Items from North Indian N. \& Q., Vol. IV
}

\author{
W. H. D. Rouse
}

To cite this article: W. H. D. Rouse (1895) Folklore Items from North Indian N. \& Q., Vol. IV, Folklore, 6:2, 207-212, DOI: 10.1080/0015587X.1895.9720303

To link to this article: http://dx.doi.org/10.1080/0015587X.1895.9720303

曲 Published online: 14 Feb 2012.

Submit your article to this journal

Q View related articles $₫$ 
Folklore Items' from North Indian N. \& Q., Vol. IV.

\author{
Popular Religion.
}

144. Bihundah Fairs-Kulu. Human sacrifice softened; now goats and sheep are sacrificed, and a man is merely lowered by $a$ rope over a cliff [instead of being thrown over]. How the rope is made. If any one steps across it, another is made; the man is fined one goat, which is sacrificed. The rope is reverenced as a deity. The right of being lowered is confined to one caste; the man chosen is fed free for the year, and receives gifts. Detailed description of the rites. Mock struggle. The man chosen is "considered a god," and worshipt. Five valuable things are put in his mouth, as at death; music played as at funeral. A very curious development is that "this year (1894) a goat was lowered instead of a man."

146. Hoshyapur. Worship of a saint. The commonest form of worship is by sleeping on the ground instead of on a bedstead. [Homer, Mliad, xvi. 232-5, gives three lines which are doubtless a traditional invocation: "Zeus, lord of Dodona, Pelasgian, dwelling afar, ruling over stormy Dodona; and round about the Selloi dwell thy interpreters, with unwashen feet, sleeping on the ground." As the Greeks were a cleanly race, and by no means ascetic, these Selloi must have been an ancient priesthood of preGreek origin. The practice existed in the fifth century and later; Soph., Tr. I167 ; Eur., Frag. 368.]

148. Impending calamity warded off by smearing all large trees with some puddle and putting pig's hair in it.

149. Case of Traga in Kathiawar. A money-lender lent money to a man, and a Charan named Saiya stood security. As it was not paid, the Charan, with his brother and mother, visited the borrower; he still refused, so the two brothers killed their old mother then and there, and the lintels were sprinkled with her blood; he then wounded the debtor. The debtor, with the guilt of a Charan's death on him, refused food, and soon died. [Case proven in court]. See No 177.

172. Saharampur: Worship of Sakambari Devi. Some dull myths. No blood sacrifices are offered to this goddess.

174. Begging grows common in Arrah (Bengal), and it is done to appease the wrath of Shiva, for a cause here related. On a certain case of disobedience, Shiva told the people to beg to pies 
(about $2 \mathrm{~d}$.), and get aith the money three breads, one to be buried, one eaten, and one given to the oxen.

176. Fasting in honour of the Sun ; certain offerings are made, amongst which is red sandal.

177. Arrah (Bengal). A legend, in which a man whose cow was stolen abstains from food and kills himself, in order to bring misfortune on the robber. [Cf. No. 149.]

2 18. The Hoi: Women's festival. The women's deities, prayers for children, and a brief legend or two.

219 . Worship of stones; e.g., milk is poured over them.

2 20. Hereditary curers of hydrophobia.

22. Worship of horse-shoes. Includes "possession," procession, and dancing on burning coals.

225. Bombay: Worship of the sea by throwing in cocoa-nuts,

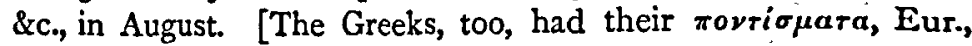
Hel. I 548.]

226. Worship of small-pox. Annual ceremony to propitiate seven sisters. Three of them attack children, and spare them only when a vow is made to wear a gold image of one of the sisters. $O n l y$ zomen do this worship, and secretly; if a man sees it, all fails. A pitcher is taken to represent each child. (Detailed account.)

227. Ghosts of Oilmen are powerful evil demons. One lives in a channel of the Sarju river, and kills many people each year. Another lives in a tree.

228. Magical ceremonies; holding hot iron, \&c., ; all effected by the aid of the Fat of Frogs.

\section{Anthropology.}

150. Children's Games.

15I. Caste changing : collection of instances.

178. Charms for cure of disease. In one, the person must go to a place where four roads meet, and pour some mixture, then retire without looking back. A second mentions red lead. A third includes a piece of the dress of the patient.

179. Hindu rites during pregnancy. 'There is fear from fairies; the males of the family must not go out in the moonlight in rich dress, for this attracts fairies, who come and plague the woman. [Surely some such idea underlies the Couvade, the man being plagued to make the malignant spirits think there is ill-luck in 
the house and not good.] Maternal uncle to the fore; also barber, as usual. No high-caste Hindu drinks in his son-in-law's house; some even refuse to drink from the well of his village.

180. Punjab Frontier,-Customs. E.g., women throw wheat upon victorious braves. Wooden effigies, or long stones set up in memory of dead relations; these are sprinkled with blood of sacrifices offered by their relations in sickness.

181. Kamdesh Priests. Certain paths tabooed.

182. Bodies not burned or buried, but put in large boxes on the hillside. Articles put in with them. Funeral dance and feast.

183. Rajputana.-Marriage Customs. Coarse chaff at weddings. $\Lambda t$ Uddipur, no women are allowed to enter the town at a marriage.

229. Snake charmers : a legend. They must be initiated.

230. Aboriginal Games. One has an explanatory legend.

231. Panjab.-Dharmsala. Sale of women : law court convictions. Mourning and birth customs (notes).

232. Young married woman goes unveiled in the quarter of the town wherein stands her mother's house, but veils herself the instant she gets into her husband's quarter.

233. Tiger lore. A man killed by a tiger appears to his kin, bidding them change their names, lest he discover them and kill them too (Garo tribe, Assam). Koi tribe (Madras) have special ceremonies at killing a tiger. $\Lambda s$ soon as it is dead, all scramble for the moustaches, which make the wearer tiger-proof; carry the body round the temple, and then up the nearest hill. The Khonds hold an oath taken upon tiger-skin inviolable. The Gonds are divided into clans, each of which have certain sacred animals which they will not eat, though the other clans will eat them. Each village has a man able to charm tigers and make them harmless. The Canarese will not speak of the tiger by name. In Bengal, he is called "maternal uncle."

\section{Folk-Tales.}

153. A Golden Horse is fished out of a river, and kept in the king's stable. Princess asks to see it, after which it refuses food. She and the horse are turned out, and live together in the jungle. He was really son of the lord of the serpents bewitched; each night he resumes his original shape and goes to bathe. While he is gone, the princess, obedient to a spy of his mother, burns his 
horse-body, and he then remains a man. Another spy tells her to ask leave to eat out of his plate; he refuses. "What caste are you, then?" she asks. "Ask no more about my caste," says he. She persists; he then suddenly raises his cobra hood and dives into the water. She follows him, and eventually both return to the world and live happily.

155. The Pious Raja and his troubles; a kind of male Griselda In this story a city appears, where the first arrival after the Raja's death is made Raja.

184. Bali Singh the Idiot (Mirzapur).-An amusing tale, including encounters with ghosts, who are browbeaten or literally whacked by the sturdy idiot.

186. Prince and Fairy Wife.-Dead resuscitated by changing the positions of two blocks of wood which lay one at each end of the cot.

187. Four hundred rupees for four pieces of Adzice (Mirzapur). - Contains familiar incidents: "Potiphar's wife ;" letter of death; when a king dies without issue, the "garland of victory" is hung round the neck of a royal elephant, which is let loose; he on whom she hangs the garland is made king.

188. (Mirzapur). - This also contains familiar incidents. Advice sold for money and tested; disguised king; faithless wife; princess whose lovers die every night. It is a stupid story.

189. The Brahnin's Riddle (Mirzapur).

21\%. Brahmin Girl married to a dog. "Beauty and the Beast," who on leaving her finally gives her a stick; if she wishes to see him, she is to place it in the sea and it will take her to him.

234. The wicked Stepmother-Queen,- Four lads start a-travelling together. They find a goat, who in two nights devours two of them. On the third, she is foiled, taking the shape of a lovely girl. A raja comes by and buys the ogress from the lads. On arriving at his palace she schemes the death of the other queens. By pretending that they ate the king's horses, she has their eyes put out, and they are cast into a pit. Each queen bore a child in turn, nine they ate, but not the tenth, who grew up, and got from a huntsman a bow and magic arrow that never missed. He is taken into the service of his father the king, and warned by his mother against the ogress.' She saw him, and pretended to be ill, saying that she needed the milk of a tigress to cure her. Hence tasks: $(x$,$) The$ 
lad was sent to get it; just as he was about to shoot the tigress, he saw she had a thorn in her foot; he pulled it out, and she gave him some of her milk; so this plot failed. (2.) Next he is sent to steal the kine of some demons. (3.) She sends him to get the "water of gold," with a letter bidding kill him. As he lay asleep on the way, Adam and Eve were flying over the jungle, and seeing him, substituted a letter which bade the ogress take care of him. In the house of the mother ogress he saw a box full of tempests, one full of rain, and in a parcel the eyes of the ten queens; also a parrot, in which lay the life of the queen-ogress; " if its leg be broken, her leg will break; if its wing be broken, her hand will break ; if it be killed, she will die." He carries off all, and the water of gold, keeping off pursuit by aid of the storm and rain from his boxes. He returns home, restores the ten queens' eyes by virtue of the water and fits them in, and before the ogress' face breaks the parrot's legs and wings and then wrings its neck. (The Ed. compares Wideawake Stories, 98 ; Jacobs' Ind. F. T., I I 5 ; and gives other parallels.)

236. Helpful Beasts.

\section{Mixed.}

158. Magic stone for rain-making.

159. Lucky to handle gold on certain days.

160. Tracing the thief: pray over bread, and a bit given all round; the thief cannot swallow it.

164. A thing which in infancy is touched by the forefinger will die early. Sometimes it is the middle finger.

I65. Instances of natives doing worship to Queen Victoria's statue, praying to her for protection and work.

r70. Charm for killing an enemy. After saying it 10,000 times certain things are to be offered to Mahábir, including red lead. Description of the familiar wax image and other sympathetic magic.

I7 I. To gain their ends, Hindus propitiate ants and fish. As a certain kind of ant is supposed to be Brahmin women, the economical worshipper gets the merit of feeding a whole host of Brahmin women at small cost.

194. Superstitions as to evil spirits and charms. The most malevolent spirits are those of a man who has died without the 
proper ceremonies, and not upon the ground; and of a woman dead within forty days of childbirth.

197. Ointment to give one the power of the Evil Eye. Kali).

198. Benares: Human sacrifice reported in the papers (to 201. Marks made on trees to secure protection of the nearest deity.

2 Ir. Omens from teething.

213. Sympathetic Magic.- "The bamboo dies when it seeds; hence it is unlucky to children to plant one near a house"

243. Native superstitions about Englishmen (amusing). Vaccinators are searching for an infant, who is to be born with milkwhite blood, and to conquer the universe. Over the inscription on a certain bridge offerings of oil-lamps and garlands are common. Others leave a handful of their wares, or at least salute the parapet. Pice are thrown into the water. Every one believes that lives are sacrificed on building a bridge. Wizard sahibs kept by Government to kill those who are found out after dark in the rains. The freemasons use their skulls to play with.

248. Nagaur. - A ewe bore a lamb under a tree, and then drove off a marauding wolf. The king thought this a good omen, and built a city there.

W. H. D. Rouse. 